\title{
Cost-Sharing in Higher Education in Tanzania: The Experiences of the 1990s and One Decade Later
}

\author{
Grace Khwaya Puja (St. Augustine University of Tanzania/IDRC Carleton \\ University)
}

\begin{abstract}
This article discusses the cost- sharing experiences of 73 Tanzanian female undergraduates who took part in a 1997 study. It also integrated views and suggestions of the 2007 students from the University of Dar es Salaam and Sokoine University of Agriculture, Mazimbu campus. The University of Dar es Salaam was closed in 2007 because First Year students boycotted classes to protest the government's policy that required them to pay $40 \%$ for their higher education.

I advocate for partnership in student financing and the introduction of graduate tax for recovering higher education students' loans.

Résumé

Cet article traite les expériences du partage des coûts de 73 tanzaniennes du premier cycle qui ont pris part à une étude en 1997. Il a également intégré les avis et les suggestions des étudiants de 2007 venant de l'Université de Dar es Salaam et de l'Université d'agriculture Sokoine du campus de Mazimbu. L'Université de Dar es Salaam a été fermée en 2007 car les étudiants de première année ont boycotté les cours afin de protester contre la politique du gouvernement qui leur a exigé de payer $40 \%$ des frais pour l'enseignement supérieur.

Je préconise un partenariat de financement des étudiants ainsi que l'introduction d'un impôt gradué afin de recouvrir les prêts des étudiants de l'enseignement supérieur.
\end{abstract}

In 1997 I conducted a study on cost-sharing in higher education in Tanzania based on the cost-sharing experiences of 73 Second Year Tanzanian female undergraduates at the University of Dar es Salaam (Main Campus), the Muhimbili University College of Health Sciences (MUCHS) and the Sokoine University of Agriculture (SUA) ${ }^{1}$. The study examined the cost-sharing experiences, views and survival strategies of the participants. The findings revealed that by 1997, the uniform amount of loan that higher education students received from the government was inadequate especially for poor students and often came late.

1 This paper was presented at the Faculty of Education Staff/Student Seminar on June 12, 2007. The author has integrated comments, views and suggestions made by the seminar participants. 
Ten years later a Faculty of Education Staff/Student seminar on the same issue was held at the University of Dar es Salaam. This discussion integrates views and suggestions of the University of Dar es Salaam who participated in the Faculty of Education Staff/Student seminar on June 12, 2007 and those expressed by the 2006/2007 students from the Mazimbu campus. These views indicate that costsharing was still a problem in 2007. The 2007 students stated that the loan was not enough, came late and; to save money they cooked their food in the residence halls, borrowed money from friends or skipped meals. One of the 2007 seminar participants referred to skipping a meal as "kupiga deshi" in Kiswahili or "going hungry" as they put it. In addition, in 2006/2007 the University of Dar es Salaam was closed from April $17^{\text {th }}$ to May 13 ${ }^{\text {th }}, 2007$ because First Year students rejected the government's regulation that required them to pay $40 \%$ of their education expenses.

\section{COST-SHARING: THE GLOBAL CONTEXT}

Cost-sharing is a problem facing many world governments due to the high demand for higher education. The World Bank (WB) and the International Monetary Fund (IMF) spearheaded tertiary and higher education reforms of the late 1980s and early 1990s that focused on the financing and management of tertiary/higher education. Developed and developing, rich and poor countries, at varying levels of technological development and diverse political orientations experienced these reforms differentially (Eboagye, 2007; 1996; Youngman, 2005; Mwinzi and Kinoti 2004; Johnstone, 1998, and World Bank, 2003). The reforms were introduced in Africa as part and parcel of the implementation of Structural Adjustment Programs (SAPs) and post-Structural Adjustment Programmes (Aboagye, 2007, Mwinzi and Kinoti, 2004). Johnstone (2006) defines "cost-sharing as "the shift in the burden of higher education costs from being borne predominantly by government, or taxpayers, to being shared with parents and students" (p.23). The Tanzanian Higher Education Students Loan Board (HESLB) adopted Johnstone's definition of costsharing as indicated in the Daily News (Friday, May 25, 2007) which states that, "Cost-sharing in higher education ...[represents]... a shift in shouldering at least part of the costs of education from Government...to the beneficiaries" (p.21). Both definitions emphasize shifting the burden of the cost of higher education from the government (tax payers) to students and their families who benefit more.

There are three major reasons provide a rationale for introducing costsharing in tertiary and higher education: first, the need for other than government revenue for higher education in response to a great demand for higher education. Higher education is a major engine of national economic growth provider at a personal level, immediate family and at a national level (Johnstone, 2006). Other scholars support this assertion including Galabawa (2005) who observes that:

In this case higher education measured in terms of the gross enrolment ratios (GER), or in terms of higher education attainment (HEA) i.e. proportion of population with higher education, was found to have a positive effect on the level of economic development (p.83).

Second, is the argument that those who benefit should at least share in the costs. 
Johnstone (2006) stresses that "free" higher education means that tax payers pay instead of students and their families who directly benefit from tertiary and higher education. The third reason is that there should be a high price on a valuable and highly demanded commodity based on market virtue such as greater efficiency (more accountability), producer responsiveness to individual and societal needs (Johnstone, 2006).

\section{COST-SHARING IN TANZANIA}

Tertiary and higher education was almost non-existent in Tanganyika ${ }^{2}$ during the the colonial period. Msolla (2007) points out that at the time of Tanganyika independence in 1961:

.... we did not have a single architect, no agronomist, no soil scientist, no surgeon, no veterinary doctor, no dentist...one agricultural engineer, one surveyor, 16 doctors, one or two graduate teachers and no single full professor, and had one or two lawyers (Msolla, 2007, p.2).

In recognition of the under-development of tertiary and higher education the new Tanganyika government under Mwalimu Nyerere heavily invested in training the high level human resources needed. Consequently, by 2007 Tanzania had 11 public universities and colleges, 17 private universities and colleges and 15 post-secondary institutions with a total enrolment of 52,586 students (Msolla, 2007; Katunzi and Fungo 2007 and Mwamba and Assad, 2007). These achievements were preceded by over 25 years of "free" education in Tanzania although in the 1960s university students were offered a bursary that they were expected to repay after graduation, but which most graduates did not repay.

For this reason and the fact that very few Tanzanians could afford to pay for tertiary and higher education, the Tanzanian government introduced cost-sharing in higher education in three phases in the early 1990s (Omari, Assad and Juma, 2002; International Comparative Education, Finance and Accessibility Project Africa Region (ICEFAPAR, 1998). Phase One of cost-sharing in higher education in Tanzania was introduced in the 1992/93 academic year. For the first time, Tanzanian students and their parents were required to pay fares to and from the university. Phase Two of cost-sharing that followed in the 1993/94 academic year required students to pay for food and accommodation, caution money and other personal costs while the government paid all academic costs and retained the responsibility to recover these costs. Phase Three would require students and parents to partially pay tuition fees, examination fees, faculty requirements, practical/field training as well as for books and stationery.

However, before Phase Three was introduced the Ministry of Science, Technology and Higher Education (MSTHE) released a comprehensive report of the Task Force in October 1998 which among other things identified 7 challenges

\footnotetext{
2 The United Republic of Tanzania (URT) or simply Tanzania was formed on April 26, 1964 when Tanganyika and Zanzibar were united.
} 
facing the financing of higher education in Tanzania including the need for economic considerations in implementing Phase Three and called for increased system efficiency (Mwamba and Asaad, 2007). The Task Force report made a number of recommendations including the use of Means Testing in assessing students' financial needs and distributing financial responsibilities among the government (82\%) and students and their families (12\%) and other sources 6\%). Omari, Asaad and Juma (2002) point out that because means testing was abused due to bribery, "everyone who applied for a loan got one even children of rich fellows and no recovery mechanism was put in place...the loan scheme is not considered equitable, nor is it efficient in targeting the poor" (p.xiii). But Omari et al also strongly recommended Means Testing as the best criterion for assessing students' financial status.

Cost-sharing continued to be one of the top agendas for the Tanzanian government and in April 2004, the Higher Education Students' Loan Board (HESLB) was established (Serikali ya Jamuhuri ya Muungano wa Tanzania, 2004). The HESLB is solely responsible for the administration of higher education students' loans in the country.

The following section focuses on the cost-sharing experiences, views and suggestions of the 1997 study participants as well as views of the 2006/2007 students.

\section{THE STUDY}

\section{Methodology}

I carried the study in 1997- three years after Phase Two of cost-sharing in higher education in Tanzania had been implemented. The study participants complained that the uniform amount of money they received from the government for meals, transport, accommodation and stationery was not enough for most of them and it often came late. Some of the participants argued that female students had more financial needs than male students because they had to buy feminine pads which male students do not need.

The 1997 study involved 73 Tanzanian female undergraduates, four recent female graduates and 18 of their instructors from three university campuses: The University of Dar es Salaam (Main Campus), the Muhimbili University College of Health Sciences and the Sokoine University of Agriculture took part in the study. Seventy-three Tanzanian female undergraduates responded to an open-ended question that I posed in the questionnaire during my study.

The open-ended question on cost-sharing was framed thus: "The Tanzanian economy is said to be in a state of economic crisis and is currently implementing the Structural Adjustment Program (SAP) aimed at improving the situation. How has the economic situation in the country affected you as a university student?"

The questionnaire responses were in English but the interviews and focus group discussions were done in Kiswahili. The narratives that are presented in the Results Section are English translations. All personal names used in this article and in the original document are fictitious. 
The University of Dar es Salaam was closed in 2007 because First Year students boycotted classes to put pressure on the government so that it would change its policy that required them to pay $40 \%$ of their educational expenses (Daily News, Friday May 25, 2007, University of Dar es Salaam, 2007). The boycott led to the closure of the University of Dar es Salaam between April $17^{\text {th }}$ and May $13^{\text {th }} 2007$. This paper integrates comments and suggestions made by the participants of the Faculty of Education Staff-Student Seminar held at the University of Dar es Salaam, on June 12, 2007 and those of the Sokoine University of Agriculture students from Mazimbu campus, D.Minja (personal communication, August 19, 2008)

\section{Results}

\section{The Participants and their Demographic Characteristics}

Racial/Ethnic Backgrounds

Thirty eight (38) of the 120 Tanzanian ethnic groups were represented in the study. Over $30 \%$ of the participants came from inter-ethnic family backgrounds. Among these $40 \%$ of them stated that at least one of their parents was either a Chagga $(26 \%)$ or a Haya $(14 \%)$. And, while there were no Asian participants at the Faculty of Engineering or at the Sokoine University of Agriculture, there were 5 Asian participants at the Muhimbili University College of Health Sciences. Despite this racial and ethnic diversity among the participants, $63 \%$ of them indicated in their questionnaires that they spoke Kiswahili at home most of the time.

\section{Religious Backgrounds}

There are almost as many Christians (45\%) as Moslems (35\%) in Tanzania (CIA, 2000). However, in the 1997 study more than $85 \%$ of the participants were Christians while slightly over $14 \%$ were Moslems.

\section{Social Class}

Most people in Tanzania are farmers but only $26 \%$ of the participants had fathers who were peasants/farmers while over $50 \%$ of the participants had fathers who were employed in various legal/administrative/managerial and professional/associate and technical occupations. In addition over $86 \%$ of the participants came from families with 4 or more children. Based on fathers' occupations over $50 \%$ of the students came from families with relatively more resources than others. However, because of low salaries and large family sizes, many of the participants of the 1997 study, the 2006/2007 students from SUA, D. Minja (personal communication, August 5, 2008 and from the UDSM, E.Luhwavi, personal communication, July $19,2008)$ argued that their parents could not afford to pay for their university education These students pointed out that the "legal/administrative/managerial and professional/associate and technical" occupations in Tanzania, included employees such as school teachers and nurses and others who are poorly paid. Therefore, only a small minority of people in Tanzania is in a position to pay for their children's university education because of the high cost of living. 


\section{The Loan for Meal Allowance}

The major concern of the 1997 study participants was the inadequacy of the loan for meals and the delays in getting it. Many of the participants stated that because the loan for meals was not enough and often came late, they cooked their food in the residences. But cooking has always been prohibited since public universities were first established in 1961. The University of Dar es Salaam Citation Number 5.2 (ii) for instance reads: "cooking is not allowed in the Halls of residence...by use of any source of energy" (University of Dar es Salaam, 2002 p. 15). This implies that students were and still are expected eat in university cafeterias. If the University Management caught them cooking in their residence halls, they were punished.

At the UDSM Main Campus (the Hill), the MUCHS and Mazimbu campus of the Sokoine University of Agriculture (SUA), students shared rooms in twos although the rooms were originally designed for one student. At the Mazimbu campus rooms were spacious and had cooking facilities because Mazimbu was originally an African National Congress (ANC) liberation movement camp. But when Mazimbu became a SUA campus, cooking was not allowed in the residences for security reasons.

Still, many of the female students brought food stuffs such as dried beans, rice, maize, sugar and once they were on campus they bought the rest of the food they needed such as meat and vegetables according to their tastes. Many of the participants stressed that cafeteria food was not only expensive and monotonous but it was also of low nutritional value or what Mazimbu students referred to as inferior commodity food."

Although rooms were small and many of them had space for only for 2 beds, two study desks and two wardrobes [fixed on the walls]. Students kept cooking stoves in their rooms and some (well to-do students) had refrigerators, televisions, video cassettes and music systems to name just a few. Students stored food stuffs such as sacks of rice, beans, and cooking as well as eating utensils in overcrowded rooms. Most of the participants of the 1997 study explained that they cooked their food in these overcrowded rooms, ate there, cleaned, stored the remaining food and often studied in the same rooms. They stressed that it was cheaper than buying their meals from university cafeterias.

\section{University of Dar es Salaam Main Campus (Faculty of Engineering-FOE)}

Vero, an Engineering student describes her 1996 experiences with the FFU (Field Force Unit) or riot police commonly known in Tanzania in Kiswahili as "Fanya Fujo Uone" (which can be literally translated as "cause trouble and you will see what happens').

Vero was an electrical engineering student who took part in the 1996 students' march to the Ministry of Science, Technology and Higher Education. She continues to narrate her experience:

We had gone to demand our meal allowance ...then we arrived at the Ministry, we waited (raises her voice to indicate fear); all of a sudden we saw the FFU police.... the tear gas bombs were thrown at us... ...And, 
while trying to escape, some of us were beaten, we were beaten, we were beaten severely... with big wooden sticks [marungu]... [The emphasis is Vero's]. The police really beat us... We had thought that the female police officers would be more lenient but they were even worse. And as they beat our heads with those big sticks, they were telling us, "You university students think that you know so much." They threatened us saying, "You will be expelled from the University..." and they beat us more than the male police officers... [The female police officers were probably more jealous or resented the female students more than the male police officers or it was a form of social class differences between the more educated female students and the less educated female police officers]. While in custody, we were given no food, and we did not sleep... We were treated like political offenders... while all we wanted was our meal allowance... the government decided to bring the FFU....The government succeeded in creating fear in some of us. I am no longer free to express myself... (Extracted from Vero's interview, 1997).

Vero argued that the government of use the FFU, a common practice whenever students demand their rights as was done in 1996, violates students 'human rights. She painfully explained that all they went to demand was their meal allowance. But Vero did not seem to suspect that perhaps the female police officers were more jealous of and resented the female university students more than did the male police officers.

The government use of the riot police during the 1996 incident and taking some of the students into custody, starving them for two days and failing to lay charges against them were all violations of human rights. The 1996 incident was not an isolated case. In 2007 the government used the FFU again to silence and/or threaten students [at the Dar es Salaam University College of Education (DUCEcampus) on April 17 th 2008 and at the University of Dar es Salaam Main Campus on May 16, 2007 when students threatened to go on a second strike because 56 of their colleagues had been suspended as the ring leaders [Vinara wa Mgomo] of the 16-17 April, 2007 students' boycotting of classes. The Ministry responsible for handling students' loans should design more democratic conflict resolution strategies and techniques.

Vero and her female colleagues were also disappointed to realize that female police officers who beat them showed no 'feminist' solidarity with them, but instead accused them of knowing "[too] much". This unexpected treatment of female university students by female police officers indicates that gender inequities need to be examined in relation to other differences such as social class differences. Vero's experiences confirm the need to avoid treating the category of "woman" as homogenous, even in Tanzania. In this situation the female police officers represent state power, and to show it, they beat the [female] university students to demonstrate to them where real power resides, namely in police officers' uniforms, tear gas and sticks [marungu] among others. 


\section{Sokoine University of Agriculture (SUA)}

The SUA participants presented cost-sharing as the most pressing issue in questionnaire responses, students' and instructors' interviews and in students' focus group discussions. They referred to it as "inadequate funds." The most affected female and male students were those who came from poor families and who entirely depended on the money from the government in the form of a loan.

SUA students who were at Mazimbu campus in 2006/2007 informed me that the loan they got from the government was not enough for their personal and educational needs. Many of them had designed personal strategies to ensure their survival. Such strategies were very similar to those used by the participants of the 1997 study. The strategies included bringing in food from home, cooking their food in the residences, borrowing money from friends or skipping meals to save money, D. Minja (personal communication, August 5,2008).

According to the participants of the 1997 study, male students who could not cook employed young or old women to cook for them for a monthly pay of about 5,000 Tanzanian Shillings. Usually, such students would be in groups of between 3-5 students. Each would contribute about 1,000/= per month and the total amount would be paid to the "house girl" (HG commonly known as 'mercury,' at SUA [HG is the scientific name for Mercury]. The participants also explained that most of the female students preferred to prepare their food rather employ a Mercury.

In 1997 there was no cafeteria at the Mazimbu campus of the Sokoine University of Agriculture. The cafeteria had been closed because no wanted to buy food offered there. However by 2006/2007 there were cafeterias at the Mazimbu campus, but many of the Mazimbu students claimed that it was cheaper to cook their meals in their residence halls. According to the 2006/2007 SUA students from Mazimbu campus, male students organized themselves in groups of between 3 to 10 students to form a "FIRM" and recruited a girl/woman known as "Mugulo. ${ }^{3}$ " to cook for the FIRM, D. Minja (personal communication, August 5, 2008). FIRM members contributed about 1,500 Tshs each that was paid to the Magulo for her services. Some female students also employed the Magulo but this was rare among female student most of whom cooked their own food either individually or in groups of two to four, D. Minja (personal communication, August 5, 2008). This gender difference in terms of cooking personal food was also observed in the 1997 study.

Zawadi, a B.SC. Food Science student at SUA-a participant of the 1997 told me that she brought sacks of rice and beans from her home in Mbeya. She said "I bring some rice and beans from home and store them in my room. I buy the rest of the food stuffs once a week and I take turns with my roommate to prepare meals in order to save money...."(Extracted from Zawadi's interview, 1997).

Zawadi's diet was made of what she and other SUA participants referred to as "cheap" commodities such as dried maize cooked with beans, Makande, rice with beans, dried sardines (Dagaa in Kiswahili) or rice and spinach. She said she

\footnotetext{
${ }^{3}$ In 1997 such a girl was known as 'Mercury' because the short form of 'House Girl' is HG a scientific name for mercury. It seems therefore that with a period of 10 years the name of mercury has been localized and it now almost sounds like a Swahili word 'magulo.'
} 
might eat beef, fruits, and vegetables once a week before the allowance is finished but she considered these a luxury because she could not afford to buy them. Zawadi also said that she could not recall when she last had eggs for breakfast.

The 1997 study participants stated that in the last months of the semester, when the loan is almost finished or delayed their survival strategies included skipping one meal a day, drinking a coke/sprite or Pepsi for lunch or chewing some gum just to get-by and have a meal in the evening.

These strategies were stated by the 2006/2007 students as well. In addition, although in 2006/2007 several cafeterias were operating at Mazimbu, the SUA Management often got complaints from cafeteria owners who alleged that they were operating at a loss because most students did not go to buy food from the cafeterias but instead cooked their own food. Consequently the SUA Management often confiscated students' cooking equipment such as stoves, D. Minja (personal communication, August 5, 2008)

The inadequacy of funds also constrained students' ability to buy learning materials such as textbooks and stationery they required for their courses. One of the 1997 study participants from SUA who was studying for a First Degree in Agriculture (BSC Agriculture General) lamented:

I can not buy books; I can not buy stationery I cannot afford to make photocopies. I cannot afford to buy any equipment as faculty requirements (I am studying Agriculture General)-Therefore, I try to carefully spend the $34,000 /=$ shillings I get from the government so that I can get all basic needs (Extract of an English translation of a SUA participant's interview, 1997).

These concerns were supported by what I observed in the 20 classroom observations I carried during the study. I noted that some of the students (female and male) came to class without pens, or paper on which to write their notes and some of these were seen borrowing such items from their colleagues sitting nearby.

Although the amount of loan for stationery, books and photocopying was increased from Tshs 34,000 in 1997 to 120,000 Tshs in 2006/2007 per year, SUA students from Mazimbu campus claimed that this amount was not enough for books and stationary. Instead, they spend this amount for photocopying and often for buying food, D. Minja (personal communication, August 19, 2008).

\section{Muhimbili University College of Health Sciences (MUCHS)}

In theory, some years ago and in practice, medical students or health sciences students were seen by other students as a privileged group. Their meals used to be balanced, and they had better accommodation services than students at the Main Campus for example. But this was not the case in 1997 when MUCHS students also faced water shortages, their washrooms and many of their toilet facilities were out of order and/or very dirty. Although rooms were still shared by only two students, the residences were old and dirty as were their lecture rooms. According to the study participants, the MUCHS diet was monotonous, the food was tasteless and 
according to Nina, an MD student, it was not uncommon to find flies in the food.

Some of the instructors that were interviewed at MUCHS (most of whom were medical doctors) were concerned that many of their students went to class hungry and that such a tendency reduced students' ability to concentrate on their studies and was detrimental to their health in the long run.

Maggie, one of the participants who was studying for a BSC Nursing degree told me that she often just took a Pepsi for lunch because she could not afford to buy boiled rice and steamed cabbage at the cafeteria that cost at least shillings $500 /=$. She explained that her mother is a single parent and she had to spend her loan money carefully because her mother could not afford to give her extra money. Maggie suggested that the provision of students' loans should take into account the realistic financial needs of students like her who have no other source of funding. She said:

I would like to suggest that we get loans from the government, those of us who can not afford to get money from any other source, not even parents. We should be given loans for the full time of our studies... to enable us complete our studies. After we complete our studies we would gradually repay the loan to the government (extract from Maggie's interview, 1997). Maggie's suggestions were supported by other participants from the three university campuses. Maggie's suggestions were also later echoed in a report on the Evaluation of the First and Second Phases of Cost-Sharing in Higher Education in Tanzania (Omari, Assad and Juma, 2002). Omari et al observe that "A loan scheme based on Means Testing requires that people [students] get the loan according to needs, which vary widely, suggesting that loan amounts should also vary" (p.xiii).

Another MUCHS student, Zena, a Medical student also describes her survival strategy which included cooking her own food in her room:

It saves a lot to cook your own food although it takes a lot of time to cook, clean and so on. But at least in terms of money, you have no problem because you know if you have no money, you can not even study that day... You will be thinking, "what will I do now?." But cleaning, dishes, you clean, it does not pain your head, you clean once, and you go to class... (Extracted from Zena's interview, 1997).

According to Zena she would rather spend time cooking and cleaning rather than worry about what to eat.

\section{DISCUSSION AND CONCLUSION}

The major cost-sharing issues in 1997 were the inadequacy of the loan and delays in getting it. The participants were also concerned that the loan amounts did not take into account their realistic financial needs. In addition, some participants said that even parents who could afford to give their children money, refused to do so claiming that students had government loans. As a result, most of the participants said that they did not have enough money to spend on their educational and personal needs. 
As pointed out in the beginning, I explored participants' cost-sharing experiences, views and their coping strategies. More specifically, I sought answers for the following questions:

(i) What are participants' experiences in cost-sharing?

(ii) How do participants cope with issues related to cost-sharing at a personal level?

(iii) What suggestions do the participants make about how to solve their financial problems especially the issue of cost-sharing?

This discussion is based on the findings of the 1997 study as well as the views and suggestions of the 2006/2007 UDSM and SUA students from Mazimbu campus.. These experiences, views and suggestions demonstrate that although students' cost-sharing experiences differed from each of the three campuses: the University of Dar es Salaam (Main Campus), MUCHS and SUA, from one student to another and from 1997 and 2006/2007, there is an overall agreement that the loans given to students, especially the money allocated for meals, stationery, textbooks and faculty requirements, were not adequate, came late and were not based on student's realistic financial needs. Students who got money from their parents and/ or close relatives (the relatively rich) were given the same amount of money as those like Maggie (the poor) who entirely depended on the loan money for all her needs that included food and her personal needs such as washing detergents and sanitary towels. The findings also demonstrate that when students took action to demand their delayed meal allowance in 1996 or to protest government policies on cost-sharing as was the case in 2007, the government called in the FFU to silence them. Some of these students were beaten, taken into custody but later released after the government failed to lay charges against them.

Although the meal allowance increased from Tshs 1,000 per day in 1997 to Tshs 5,000 per day by 2007, the University of Dar es Salaam students and the SUA students from Mazimbu campus asserted that the uniform amount of loan for the meal allowance, books and stationary was inadequate (See APA for citation format Personal correspondence).

The 2006/2007 students specifically blamed the Higher Education Students Loan Board (Serikali ya Muungano wa Tanzania, 2004) for delaying the loan for meal allowance

The 1997 participants such as Maggie who entirely depended on the loan suggested that loans decisions should be based on their realistic needs and the amount given should enable them to pursue their undergraduate programs. The 2006/2007 students also suggested that loans should be based on their realistic financial needs. They recommended Tshs 10,000-1200,000 per day for food alone instead of Tshs 5,000 that they were given in 2006/2007, E. Luhwavi (personal communication July 19, 2008 and D. Minja (personal communication, August 5, 2008).

In the 2006/2007 academic year the HESLB introduced a new requirement for all $1^{\text {st }}$ Year Tanzanian students admitted into higher education institutions. The new requirement stipulated that students would get government loans to cover only $60 \%$ of their training and field practical and they pay $40 \%$ of these expenses 
either on their own or with the financial support from parents/relatives/guardians ((Higher Education Students' Loans Board, 2006 and HESLB Act No 9 of 2004, HESLB, 2005). The HESLB aimed at offering loans to more applicants than it did previously when it offered a 100\% loan to all eligible applicants. But this regulation was rejected by the University of Dar es Salaam First Year in April 2007 forcing the government to close the University of Dar es Salaam for one month. Therefore, apart from the meal allowance being inadequate and often coming late in 2007, First Year students were required to pay $40 \%$ of their educational expenses

The Higher Education Students' Loan Board introduced Means Testing as a system for determining students' financial status in 2007/2008 academic year. Based on the results of Means Testing, the prospective borrowers would get a loan that would get loans varying from $0 \%$ to $100 \%$ to cover their educational needs. The new approach was expected to enable the HESLB to offer loans based on students' real financial needs. Students who did not need loans were to pay for all their higher education expenses. The First Year University of Dar es Salaam students opposed this requirement. Consequently the HESLB decided to offer loans to male students who scored First and Second Class and female students who scored First, Second and Third Class in the National Form Six Examinations. Those who scored lower grades were not to be offered loans. But later the government identified some programs such as education and medicine as key programs which would be completely supported financially. This implied that students who were enrolled in these programs were given loans to cover $100 \%$ of their educational costs. The rest of the students were required to pay for their higher education.

Cost-sharing is a world-wide concern. Developing, rich and poor countries have employed various strategies in financing higher education since the 1990s. Hauptman (2007) summarizes these strategies into four models: Model OneExpansion of a public sector charging little or no tuition fees; Model Two-publicly financed fees repaid through the tax system once students graduate, Model Three: Increased cost sharing with higher levels of student aid and Model Four: Expansion of a private sector of institutions (Hauptman 2007, p 3).

Other strategies based on African experiences include asking for contributions from parents and relatives as they do in Ghana (Aboagye, 2007). Similarly, other countries such as Canada, Botswana and Malaysia have saving schemes for post-secondary/higher education. I argue that if a saving scheme is introduced in Tanzania, it would allow students from the lower economic stratum of the society such as Maggie, a BSC Nursing student, to get a bursary/grant for their education.

Malekela (1999) among others, point out that access to higher education in Tanzania is influenced by ethnicity, religion, rural/urban diversity, ability and the socio-economic backgrounds among other factors. This implies that the Tanzanian government should not adopt funding strategies that further minimize the representation of the marginalized social groups in higher education.

How students should repay the loans they are given for their higher education is an issue of concern worldwide. Aboagye (2007) presents a number of possible approaches recommended by Albrecht and Ziderman (1991) on how 
students could repay their loans. But she recommends that African governments should consider recovering higher education students' loans through the introduction of a graduate tax (GT) which is practiced in Australia and New Zealand, Botswana and Ethiopia (World Bank, 2003). The World Bank further calls for a specific regulation for recovering higher education students' loans from self-employed graduates. Self-employed graduates could repay their loans as part of a fee they pay when obtaining licenses for their businesses through the Tanzania Revenue Authority (TRA). The money so recovered from graduate tax (GT) would create a sustainable revolving fund for financing higher education in Tanzania.

\section{Recommendations}

I make the following suggestions to improve cost-sharing efforts in Tanzania:

(i) Review the Higher Education Students' Loans Board Act to include fund raising and establish a sustainable Higher Education Fund (HEF) among its functions.

(ii) Create a sustainable electronic database based on students' school records to facilitate identification of students' financial status.

(iii) Abolish the policy of giving loans to students who score Division 1 and 2 in Form Six Examinations results.

(iv) Establish a partnership in funding tertiary and higher education to involve all higher education stakeholders

(iv) Establish a system of offering scholarships, awards and bursaries based on merit and work-studies based on financial need

(v) Create and offer part-time and on-campus employment for undergraduates and graduate and teaching assistantships for Maters and doctoral students so that they can partially pay for their education

(vi) Review the university curriculum to allow for part-time study for working students

(vii) Create more and diversified types of tertiary and higher education institutions to include community colleges, polytechnics, adult, continuing, distance and/on-line education institutions that use diverse pedagogical modes.

(viii) Introduce Graduate Tax (GT), income contingency or their variations to recover higher education loans from graduateslearn from the experiences of other countries such as Botswana, Ethiopia and Australia. Self-employed graduates should repay the loan through the Tanzania Revenue Authority (TRA) as part of their business licenses. This money should used by the HESLB to create a sustainable revolving fund for financing higher education in Tanzania.

There is need for further research that would address the following issues:

(i) How has the loan policy influenced the student population in Tanzania? 
(ii) What are the socio-economic backgrounds of Tanzanian higher education students? and

(iii) The living conditions of Tanzanian students in tertiary and higher education institutions, as well as

(iv) The effects of cost-sharing on the quality of tertiary and higher education in Tanzania.

\section{References:}

Aboagye, Eva. (2007). "Financing Students in Higher Education: Examining Trends and Funding Options in Africa and Canada." In: Dlamini, S.Nombuso (Ed). New Directions in African Education: Challenges and Possibilities (Africa): The Missing Voices Series. Alberta: University of Calgary [Forth coming].

Daily News, Friday May 25, 2007, Guidelines and Criteria for Granting Students Loans for 2007/2008 Academic Year. Higher Education Students Loan Board (HESLB) p.21-23.

Galabawa, Justinian.C.J. (2005). "Returns to investment in Education: Startling Revelations and Alterations before Tanzanians": Professorial Inaugural Lecture Series No. 45. Dar es Salaam: University of Dar es Salaam.

Hauptman, Arthur M. [2007] Financing Higher Education: Four Models of Growth .Accessed on May 4, 2007, from http://www.bc.edu/bc_org/avp/soe/cihe/newsletter/ Number46/p2_Hauptman.htm

Higher Education Students' Loans Board (HESLB). (2005). Higher Education Students'Loan Board Regulations 2005: Repayment and Recovery of Loans [Part V Sections 2727-34]. Dar es Salaam: United Republic of Tanzania. Ministry of Higher Education Science and Technology.

Higher Education Students' Loans Board. (HESLB) (2006). Guidelines and Criteria for Loan Application Starting 2006/2007. Dar es Salaam: United Republic of Tanzania. Ministry of Higher Education Science and Technology.

Johnstone, D. Bruce (1998). The Financing and Management of Higher Education: A Status Report on worldwide Reforms. (With Alka Aora and William Experton). Buffalo, New York. Accessed on May 3, 2007, from http://www.bc.edu/bc_org/avp/soe/ cihe/policyfinance_educatioN_WB.pdf

Johnstone, D. Bruce. (2006). "Financing Higher Education: Cost-Sharing in International Perspective-Financing." Higher Education Series: Global Perspectives, Volume 3. Series Editor, Philip G. Altbach. Buffalo New York: Comparative International Higher Education (CIHE). Accessed on June 9, 2007, from http://www. sensepublishers.com

Katunzi, Naomi and F.A. Fungo (2007). "Towards Effective Strategies for Expanding and Consolidating Tertiary and Higher Education." Paper presented at the Ministry of Higher Education, Science and Technology Stakeholders' Workshop on Tertiary and Higher Education Development and Management Strategy held at Kunduchi Beach Resort, Dar es Salaam, June $7^{\text {th }}$ to $8^{\text {th }} 2007$.

Malekela, George. A (1999). "Access to equity in university education in Tanzania," 
Perspectives in Education, 15: (1), 34-36.

Msolla, Peter. (2007). "Opening Speech", for the Stakeholders Workshop on Tertiary and Higher Education. Kunduchi Beach Resort, Dar es Salaam. June $7^{\text {th }}$ to $8^{\text {th }} 2007$.

Mwamba, Natu E. and Mussa J. Assad (2007). "Effective Financing of Tertiary and Higher Education Sector: An Argument for Performance-Informed Financing Strategy Based". Paper presented at the Ministry of Higher Education, Science and Technology Stakeholders' Workshop on Tertiary and Higher Education Development and Management Strategy held at Kunduchi Beach Resort, Dar es Salaam, June $7^{\text {th }}-8^{\text {th }} 2007$.

Mwinzi, Dinah C. and Jacinta W. Kinoti [2004] "The Impact of Cost-sharing Policy on the Living Conditions of Students in Kenyan Public Universities: The Case of Nairobi and Moi Universities," Study Programme on Higher Education Management in Africa Association of African Universities Project, African Region, Accra-North Ghana. Accessed on May 11, 2007, from http://www.aau.org/studyprogram/ dbfiles/index.htm?pageNum_Recordset $1 \mathrm{db}=3$

Omari, Issa M., Mussa J. Assad and Ibrahim H. Juma (2002). An Evaluation of the First and Second Phases of Cost-Sharing in Higher Education in Tanzania. Unpublished, Ministry of Science, Technology and Higher Education, United Republic of Tanzania.

International Comparative Education, Finance and Accessibility Project Africa Region (ICEFAPAR, 1998).Tanzania: A Brief description of the higher education system in Tanzania, accessed on May 6, 2007 from http://www.gse.buffalo.edu.org/ inthigheredfinance/region_africaTanzania.htm

United Republic of Tanzania (2004). Hotuba ya Waziri wa Sayansi Technolojia na Elimu ya $Ј и u$ [Minister for Science, Technology and Higher Education] Mheshimiwa, Pius Ng'wandu. Dar es Salaam: Dar es Salaam University Press [DUP].

University of Dar es Salaam (2002). Students' By-Laws (As amended in November 1999 and in November 2001. Issued by The Office of the Chief Administrative Officer, September 2002. Dar es Salaam: University Press (DUP).

University of Dar es Salaam (2007). Fees Structure: The Revised Tuition Fees for Tanzanian

Students Effective 2007/2008 Academic Year. University of Dar es Salaam:

Office of the Deputy Vice Chancellor Academic, Research and Consultancy,

Directorate of Undergraduate Studies

University of Dar es Salaam (2007) Press Release; All Undergraduate Students, University of Dar es Salaam. University of Dar es Salaam. April $18^{\text {th }} 2007$.

World Bank (2003). Higher Education Development for Ethiopia: Pursuing the Vision. A World Bank Sector Study. Document of the World Bank. Accessed on May 12, 2007, from http://www1.worldbank.org/education/tertiary/documents/EthiopiaHigherEd_ESW012004.pdf

Youngman Frank (2005). Tertiary Education Policy for Botswana: Challenges and Choices. Consultation Paper Prepared by the Working Group on the Tertiary Education Policy for Botswana. February 2005. Accessed on May 12, 2007, from http://www. moe.gov.bw/headquarters/TEC/Tertiary\%20Education\%20Policy\%20for\%20 Botswana.pdf 


\section{Glossary of Kiswahili Words Used in the Article}

Bunge-Parliament

Dagaa-dried sardines

Fanya Fujo Uone" 'Cause trouble and you will see what happens.'

Magulo-a newly coloqual word used by Mazimbu in 2006/2007 academic year to describe a woman hired to cook for the 'FIRM-a group of 3-10 male students who share the services of Magulo'

Makande-dried maize cooked with beans

Marungu-big wooden sticks

Mliman- at the Hill

Kupiga deshi [-] to skip a meal or "go hungry"

Vinara wa Mgomo-Ring leaders

Serikali ya Jamuhuri ya Muungano wa Tanzania- the United Republic of Tanzania

Grace Khwaya Puja is a Visiting Scholar at the International Development Research Centre of Carleton University and is also a Senior Lecturer at St. Augustine University of Tanzania, and can be reached at changamod@yahoo.com. 